\title{
Effect of Different Inorganic Substrates on Growth Performance of African Catfish (Clarias gariepinus, Burchell 1822) and Lettuce (Lactuca sativa L.)
}

\author{
Murat Yeşiltaş, ${ }^{1,2, a}$, Mehmet Ali Turan Koçer ${ }^{1, b}$, Hüseyin Sevgili ${ }^{1, c}$, Edis Koru ${ }^{2, d, *}$ \\ ${ }^{I}$ Department of Environment and Resource Management, Mediterranean Fisheries Research, Production and Training Institute, 07570 \\ Demre/Antalya, Turkey \\ ${ }^{2}$ Department of Aquaculture, Faculty of Fisheries, Ege University, 35100 Bornova/İzir, Turkey \\ *Corresponding author
}

A R T I C L I N F O A B S T R A C T

Research Article

Lettuce (Lactuca sativa L.) and African catfish (Clarias gariepinus) were preferred to grow in aquaponics due to their high and fast productivity growth. However, limited research was conducted on the impact on different inorganic substrates' growth performance in aquaponics. In this study, lettuce's growth performance was determined in four different kinds of inorganic substrates in

Received : 25/10/2020

Accepted : 23/11/2020 Nutrient Film Technique (NFT) aquaponics by measuring final weight, daily growth rate, stem diameter, plant and root lengths, leaf number per plant and shoot/root ratio. Polyester fiber, rock wool, zeolite, and gravel were used as inorganic substrate materials. A constant flow rate of 0.3 $\mathrm{L} / \mathrm{min}$ was maintained using with a submersible pump motor. At the end of the study, the African catfish's feed conversion ratio was estimated to be 0.66 , while the specific growth rate (SGR) was $2.3 \%$. Total lettuce yields for polyester fiber, rock wool, zeolite and gravel were obtained as

Keywords:

Aquaponics Inorganic substrate

African catfish

Clarias gariepinus

Lactuca sativa
$5.072,22 \mathrm{~kg} / \mathrm{m}^{2}, 4.934,03 \mathrm{~kg} / \mathrm{m}^{2}, 6.067 \mathrm{~kg} / \mathrm{m}^{2}$, and $5.382,64 \mathrm{~kg} / \mathrm{m}^{2}$ respectively. There were statistically significant differences for daily growth rate between the inorganic substrates that the significantly highest values were recorded in the zeolite. The results revealed that initial plant length and shoot/root ratio were the significant factors on the growth performance for lettuce in aquaponic system tested. The best lettuce yield performance was observed in zeolite substrate but, economically available option was found as gravel for hydroponic troughs.

\section{Introduction}

Freshwater demand has tripled over the past 50 years and it has been increasing in parallel with population growth (Molden, 2017). Since, most freshwater is mainly used for food production, the sustainability of food and drinkable water is becoming more critical every year. According to Food and Agriculture Organization the average withdrawal of freshwater is 350 tonnes/year per capita globally, and agriculture is by far the biggest user of water (FAO, 2016). The water withdrawal ratios are $69 \%$ for agriculture, $12 \%$ for municipalities, and $19 \%$ for the industry. For more sustainable production and wellmanaged freshwater resources and wastewater treatment programs or systems, recirculating aquaculture systems (RAS) have remarkably gained importance. In RAS, ammonia excreted by fish is converted to nitrite and nontoxic nitrate by the genera of Nitrobacter and Nitrospira (Cebron and Garnier, 2005) at a suitable $\mathrm{pH}$ range between 7 and 8.5 (Tyson, 2004; Blackburne et al., 2007).
Aquaponics is another type of RAS that includes symbiotic fish-vegetable-bacteria co-culturing in the same system (Rakocy, 2012). Aquaponic systems are relatively new compared to other aquaculture production systems considering that research studies on it started in the $1980 \mathrm{~s}$ (Rakocy, 1984).

In addition to benefits for aquaculture production and water use of aquaponics, it is the soil-free production of plants, meaning that farmers can grow plants without using chemical fertilizers, herbicides or pesticides for plants (Milicic et al., 2017). The density of aquaponic plant production is directly linked to the aquaculture water's nutrient content, which is closely associated with the amount fish, feed quantity, and feed nutrient compositions. There are 16 macro and micronutrients such as nitrate, ammonium, phosphate, etc. for well-grown plants balanced with each other in aquaponics. All of these organic and inorganic factors in the aquaponics affect fish and plant growth 
(Somerville et al., 2014). The cultivation of plants in aquaponics systems have advantageous with their clean leaf production (Nicola et al., 2005). Another advantage of aquaponics is that it is well suited for urban environments since it requires a relatively small space. With this advantage alone, aquaponics can be located close to consumers, reducing cost of transportation, packaging, and storage of products (Rakocy et al., 2006; Somerville et al., 2014).

The main principle in aquaponics is the transformation of fish feces and uneaten fish feeds to useful plant nutrients such as nitrate, ammonium, and phosphate (Chen et. al., 1997). Sengbusch et al. (1967) firstly tried to determine the problems in RAS. Sneed et al. (1975) studied fish farming and hydroponics together before Rakocy et al. (1984) started to set up their first commercial-scale aquaponic systems at the University of Virgin Islands. Also McMurtry et al. (1990) built the first aquaponic system containing fish, plants and bacteria units and studied blue tilapia (Sarotherodon aureus L.) and some plants e.g. bush bean (Phaseolus vulgaris L.), cucumber (Cucumis sativus L.) and tomato (Lycopersicon esculentum) in Greenhouse. These pioneering studies were followed with other combinations such as tomato (Solanum lycopersicum)tilapia (Watten and Busch, 1984; McMurtry et al., 1997), lettuce (Lactuca sativa)-tilapia (Oreochromis niloticus) (Rakocy et al., 1997), basil (Ocimum basilicum)-lettuce (Lactuca sativa)-rainbow trout (Onchorynchus mykiss) (Adler et al., 2001), basil (Ocimum basilicum)-okra (Abelmoschus esculentus)-tilapia (Orechromis niloticus) (Rakocy et al., 2004), lettuce (Lactuca sativa)-Murray cod (Maccullochella peelii) (Lennard and Leonard, 2006), lettuce (Lactuca sativa)-tomato-pepper-cucumberbarramundi (Nelson, 2007) and cucumber-tilapia (Tyson et al., 2008).

Substrates are commonly used components for soilless plant production systems. The type of different substrates is known to have direct and indirect effects on plant yield such as on germination (Gell et al., 2011), phytotoxic effect (Abdullahi et al., 2008), growth (Sanchez et al. 2008). Several studies on the effectiveness of substrates in the hydroponic part of aquaponic systems have been carried out. In a study by Jordan et al. (2018) five substrates including crushed stone, zeolite, coconut shell fiber, phenolic foam and expanded vermiculite were tested in aquaponics and phenolic foam presented in the lowest lettuce yield with $1.94 \mathrm{~kg} / \mathrm{m}^{2}$ while coconut shell fiber generated the highest yield with $2.88 \mathrm{~kg} / \mathrm{m}^{2}$. Sole perlite, $75 \%$ perlite $+25 \%$ cocopeat, $\% 50$ perlite $+\% 50$ cocopeat, $25 \%$ perlite $+75 \%$ cocopeat and sole cocopeat substrates were investigated to determine the strawberry yield in aquaponics and higher levels of perlite positively influenced the production (Roosta, and Afsharipoor, 2012). In another study, flexible polyurethane foam was found to be a better substrate than crushed stone for lettuce production combined with tilapia production (Geisenhoff et al., 2016). Mineral wool and vermiculite were better substrates than perlite, coconut fiber, hydroleca, sphagnum moss, algae, and charcoal substrates in terms of spinach, chicory and basil production in aquaponic over the summer and autumn sessions (Khandaker and Kotzen, 2018; Nuwansi et al., 2016). A recent experiment found that lightweight expanded clay aggregate (LECA) as substrate yielded a higher lettuce product than the floating raft although the latter showed longer plant root (Velichkova et al., 2019).

Briefly, the use of different substrate in aquaponic systems may bring several benefits in terms of plant production and water quality by providing a different media for nitrogen converting bacteria and acting as a particle filter medium but not without some reservations such as clogging, the formation of death zones and cleaning difficulty (Rakocy et al., 2006). The latter issues are significant for smooth operation during and between the growing periods. Using substrate in only seedling baskets may be a solution for the problems but this issue has never been studied. Therefore, the present study was planned to investigate the effects of commonly available cheap inorganic substrates in only seedling baskets on plant production (lettuce) in an aquaponic system.

\section{Materials and methods}

\section{System Setup}

This experiment was conducted from April 1st to May 12th 2019 under Mediterranean climate conditions at the Kepez Unit of Mediterranean Fisheries Research Production and Training Institute (MEDFRI), Antalya, Turkey. The aquaponic system was set up with one circular rearing tank (2500 L water capacity) with dual drain, twoparticle sedimentation tanks (each $80 \mathrm{~L}$ ), two nitrification tanks full of biomedia (each 140 L), 12 hydroponic troughs (each 21,6L) and one sump tank (140 L). The overall dimension of the system is about $20 \mathrm{~m}^{2}$ (Figure 1 ).

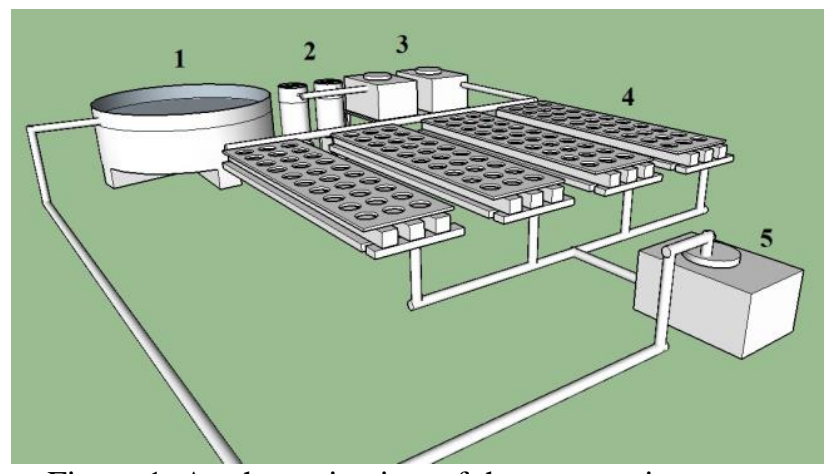

Figure 1. A schematic view of the aquaponics system used for this study 1. Rearing Tank, 2. Radial Flow

Separators, 3. Biofilters, 4. Plant Rafts, 5. Sump/Pump

Lactuca sativa (curly leafed variety of lettuce) is the most common plant for use in aquaponics. In this study, four different inorganic substrates, fiber, rock wool, zeolite and gravel, were used to determine their suitability for lettuce performance at a constant flow rate of $0.3 \mathrm{~L} / \mathrm{min}$. Lettuce seedlings were obtained from a local greenhouse. Each substrate was tested in triplicated troughs. A total of onehundred twenty 3-6 leafed seedlings were used in the system, i.e., ten pieces of lettuce were tested in each trough. For the plantation of seedlings, styrofoam boards and foam cups were used as plant carrier. The seedlings' initial weight and length were $2.18 \mathrm{~g} \pm 0.47 \mathrm{~g}$ and $113.2 \mathrm{~mm} \pm 13.17 \mathrm{~mm}$, respectively. Planting distance between seedlings was equidistant at $12 \mathrm{~cm}$. Fe-EDDHA supplementation was used three times as a chelated iron agent at dose of $2 \mathrm{ppm}$ to protect the plants against chlorosis. Only natural sunlight 
and photoperiod during April 1st-May 12th 2019 were used in the system. At the end of the experiment, plants were harvested, final weight, specific growth rate (g/day), final stem diameter $(\mathrm{mm})$, final plant length $(\mathrm{mm})$, final root length $(\mathrm{mm})$, final leaf number per plant and shoot length/root length ratio were calculated.

African catfish, Clarias gariepinus, used in the experiment were obtained from a large population produced at the hatchery of MEDFRI. A total of 207 African catfish with an initial average weight of $48.32 \pm 12.84 \mathrm{~g}$ (initial stocking density of $5 \mathrm{~kg} / \mathrm{m}^{3}$ ) was stocked. Fish were fed with a commercial extruded trout feed with $6 \mathrm{~mm}$ diameter containing $45 \%$ crude protein, $20 \%$ crude lipid, $10 \%$ crude ash, $1 \%$ crude cellulose, $1.2 \%$ calcium, $1.1 \%$ phosphorus, $0.3 \%$ sodium, $12 \%$ moisture. Feeding was done twice a day at 9 a.m. and 4 p.m. Feeding level was adjusted at $0.75 \%$ of total biomass during the first two weeks, $1.4 \%$ during 2-4 weeks, $2.8 \%$ during the last weeks of the experiment considering water temperature. Sludge consisting of the fish feces and uneaten feed accumulated in the sedimentation tanks was removed from the system.

Hydraulic Retention Time (HRT) was calculated using the following formula. HRT= Water Flow Rate (L/day) / Raft Volume (L).

Feed conversion ratio (FCR) is a good instrument to determine of acceptability of fish feed for fish. The feed conversion ratio was computed in accordance with the following formula (Jhingran, 1991). FCR= Total amount of feed $(\mathrm{kg}) /$ Total amount of fish produced $(\mathrm{kg})$. Specific growth rate of African catfish was calculated using as following formula.

$$
\begin{aligned}
& \mathrm{SGR}=\ln (\mathrm{MW} 1)-\ln (\mathrm{MW}) \times 100 / \text { number of days } \\
& \text { MW1 }: \text { Mean weight at day } 42(\mathrm{~g}) \\
& \text { MW2 : Mean weight at day } 1(\mathrm{~g})
\end{aligned}
$$

\section{Water Quality}

All water quality parameters measured daily in the aquaponics are shown in Figure 2. Before the commencement of this study, an adaptation period of one month was implemented for a steady-state Nitrosomonas and Nitrobacter bacterial biomass in the biofilter converting ammonia nitrogen to nitrite and nitrate respectively. To accumulate right amount of nitrification bacteria in a biofilter tank, some African catfish were fed with commercial feed in that period before the study. Water temperature $\left({ }^{\circ} \mathrm{C}\right)$, dissolved oxygen $(\mathrm{mg} / \mathrm{L})$, oxygen saturation $(\%)$, conductivity $(\mathrm{mS} / \mathrm{m})$ and salinity $(\mathrm{ppt})$ were measured using a handheld multiparameter instrument (model ProDSS, YSI Inc., Yellow Springs, Ohio) in the field, $\mathrm{pH}$ values are determined by benchtop instrument in the laboratory (Orion 4 Star, Thermo Scientific). All parameters were measured twice a day before feeding.

To determine ion concentrations, weekly water samples are collected from close to the inlet of each unit of the system (fish rearing, sedimentation, biofilter and sump tanks). Each water sample filtered with $0.45 \mu \mathrm{m}$ filters before analysis with $10 \mathrm{~mL}$ sample volume. Ammonium, nitrite, nitrate, phosphate, potassium, magnesium, calcium, sulfate, chloride, sodium ions were determined using ion chromatography (Dionex ICS 3000, Thermo Scientific, Waltham, Massachusetts, USA) according to the manufacturer instructions. Total suspended solids (TSS) were determined gravimetrically using $0.7 \mu \mathrm{m}$ glass fiber filter disks (APHA, 1998).

\section{Statistical Data Analysis}

The statistical analyses were performed using JMP 7 Software (Ver. 12.2, SAS Institute Inc., Cary, N. C.), using variance (One-way ANOVA) followed by Tukey's HSD post comparison test was performed. Confidential interval was $95 \%$, and results were given as mean \pm standard deviation.

\section{Results and Discussion}

No fish death and no fungal and bacterial diseases were detected over the study period. The fish demonstrated productive growth. Fish grew from $48 \mathrm{~g}$ to $133 \mathrm{~g}$ over 42 days of experiment with a specific growth rate of $2.36 \%$ (Table 1). African catfish specific fish growth rate was found better in comparison to some other studies such as $0.48 \%$ (Baßmann et al., 2017), $1.68 \%$ to $1.80 \%$ in different hydraulic loading rates (Endut et al., 2010), 0.73\% to $0.80 \%$ in different plant (Ocimum basilicum) densities (Baßmann et al., 2020). The feed conversion ratio of African catfish kept in the aquaponic system here were calculated as 0.66, which is better than those reported for African catfish maintained in conventional and recirculating aquaculture (Hogendoorn et al., 1983; Strauch et al., 2018) as well as in aquaponic system (Palm et al., 2014). Better FCR result of this study might linked to fish wealth in fish tank. Total suspended solids (TSS) in recirculating aquaculture systems have a potential for African catfish wealth. African catfish likes to live in turbid water TSS is directly related to the amount of fish feed, fish feces and microorganisms decomposition and decay. TSS caused turbid water in fish tank and this may have caused to visual restriction among fish. Visual restriction might have prevented fish fight for territory and TSS depended turbidity may have directly increased the FCR value and survival rate (Mukai et al., 2013). The study's total fish production was $27.56 \mathrm{~kg}$ with a stocking density of 11 $\mathrm{kg} / \mathrm{m}^{3}$, suggesting that the aquaponic system used provided acceptable water quality over the experimental period.

Table 1. Growth and feed conversion of African catfish (Clarias gariepinus) reared in aquaponic system for 42 days

\begin{tabular}{l|c}
\hline \multicolumn{1}{c|}{ Parameters } & Weight \\
\hline Initial weight (g/fish) & $48.32 \pm 12.84$ \\
Final weight (g/fish) & $133.1 \pm 57.1$ \\
Specific growth rate (\%/day) & 2.36 \\
Harvest weight $(\mathrm{kg})$ & 27.56 \\
Stock density at harvest $\left(\mathrm{kg} / \mathrm{m}^{3}\right)$ & 11.02 \\
Survival rate $(\%)$ & 100 \\
Feed Conversion Ratio (FCR) & 0.66 \\
\hline
\end{tabular}

Water temperature at the beginning of the study increased from $14.5^{\circ} \mathrm{C}$ to $24^{\circ} \mathrm{C}$ in the last period of the experiment, depending on the environmental temperature (Figure 2). There was a decreasing trend in dissolved oxygen concentrations in the whole system, which appears 
to increase fish mass, feeding level, and water temperature. Expectedly, dissolved oxygen levels were lower in sedimentation and biofilter tanks compared with the other units, considering that a remarkable oxygen consumption of heterotrophic bacteria in the former, and Nitrosomonas and Nitrobacter in the latter (Hagopian and Riley, 1998; Davidson et al., 2008; Ebeling and Timmons, 2012).
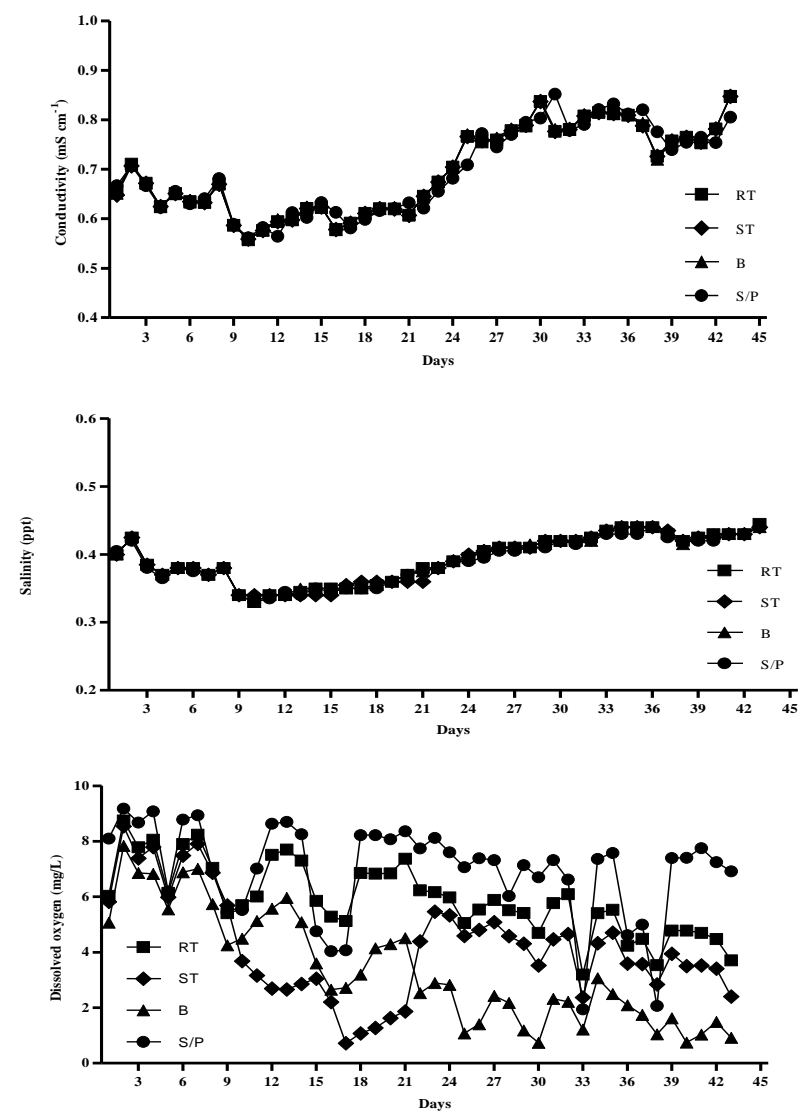

Figure 2. Variations of physicochemical water quality of aquaponics units

There was an increasing electrical current (EC) and salinity trend in all sampling points over the study period, with no significant differences between the system's parts (Figure 2). This trend seems to have a slight plateau during the last part of the study, being consistent with Danaher et al. (2013) observations, who underlined the importance of increasing feed usage with growing fish size over the culture period daily increased 10 to $15 \mathrm{~g} / \mathrm{m}^{2} / \mathrm{d}$. Feed usage, indeed, can result in more nutrient and ion accumulations with concomitant increase of EC in aquaponic systems (Maucieri et al. 2019). However, lettuce's increasing nutrient demands during the final stage may have played a role in slowing or leveling off the trend in EC and salinity as underlined by Lennard and Leonard (2006) and Palm et al. (2014).

A general increasing trend of dissolved cations and anions from the beginning to the trial ending was observed (Figure 3). Although ammonia concentrations in particle separation tanks were higher than other parts during the first four weeks changing in a range of $<0.3-1.20 \mathrm{mg} / \mathrm{L}$, the difference was not statistically significant $(\mathrm{P}>0.05)$. Other studies such as Antoniou et al. (1990), Marschner (2003)
Dissolved oxygen concentrations and saturation in the sump tank were significantly higher than the radial flow separator tank and biofilter tank $\left(\mathrm{F}_{a, b}=36.081, \mathrm{P}<0.05\right.$; $\mathrm{F}_{a, b}=42.037, \mathrm{P}<0.05$ respectively). In fish rearing tank, dissolved oxygen concentration was between 3 and $9 \mathrm{mg} / \mathrm{L}$ which was suitable for catfish culture (Toko et al., 2007).
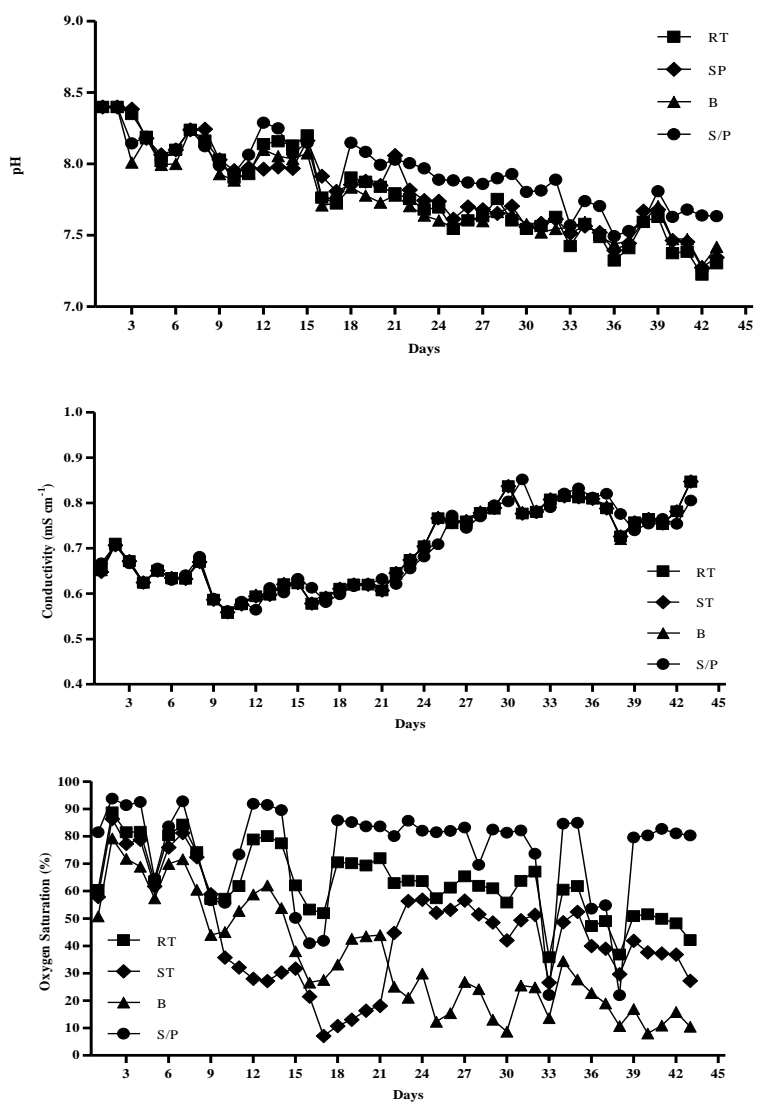

and Tyson et al. (2011) have demonstrated that low temperatures mostly increased the reliance of primary producers on ammonium rather than nitrate as a $\mathrm{N}$ resource. Toxic effects of high levels of unionized ammonia in aquaponic water are buffered by low $\mathrm{pH}$ (Wurts, 2003), which was possibly the case in the present study with decreasing $\mathrm{pH}$ trend over the study period be seen in Figure 1. Nitrite concentrations showed a higher variation between units of the system. Indeed, significant differences $(\mathrm{P}<0.05)$ in the concentrations were determined with higher values in the separation tank than the biofilter tank. Nitrite concentrations increased highly in all parts of the system in the last part of the trial with a change from $<0,00$ to $2.00 \mathrm{mg} / \mathrm{L}$, except for the sump tank. Nitrate accumulations were observed in all aquaponics units thanks to the bacterial nitrification activity, and the maximum level reached $222.78 \mathrm{mg} / \mathrm{L}$. Although nitrate concentrations higher than $140 \mathrm{mg} / \mathrm{L}$ were not suggested for African catfish due to reduced feed intake and growth performance (Schram et al. 2014), the maximum level recorded here appeared to be no problem for fish considering excellent growth rate and FCR. 
Table 2. Growth parameters of whole plant reared in different substrates in an aquaponics system for 6 weeks.

\begin{tabular}{l|ccccccc}
\hline & Polyester Fiber & Rock wool & Zeolite & Gravel & ANOVA & CV $(\%)$ & Tukey-HSD \\
\hline IPL $(\mathrm{mm})$ & $113.8 \pm 11.1^{\mathrm{a}}$ & $117.8 \pm 12.5^{\mathrm{a}}$ & $119.9 \pm 9.7^{\mathrm{a}}$ & $101.1 \pm 13.5^{\mathrm{b}}$ & $\mathrm{P}<0.01$ & 0.11 & 8.05 \\
FPL (mm) & $502.5 \pm 62.3^{\mathrm{ab}}$ & $525.1 \pm 69.6^{\mathrm{a}}$ & $485.6 \pm 67.2^{\mathrm{b}}$ & $326.5 \pm 34.6^{\mathrm{c}}$ & $\mathrm{P}<0.01$ & 0.11 & 35.02 \\
IRL (mm) & $58.0 \pm 7.5^{\mathrm{ab}}$ & $59.0 \pm 8.3^{\mathrm{a}}$ & $58.5 \pm 7.6^{\mathrm{ab}}$ & $53.2 \pm 9.5^{\mathrm{b}}$ & $\mathrm{P}<0.05$ & 0.15 & 5.66 \\
FRL (mm) & $298.2 \pm 56.4^{\mathrm{b}}$ & $335.6 \pm 60.7^{\mathrm{a}}$ & $275.9 \pm 54.7^{\mathrm{b}}$ & $140.5 \pm 25.7^{\mathrm{c}}$ & $\mathrm{P}<0.01$ & 0.14 & 25.61 \\
ISD (mm) & $2.7 \pm 0.3^{\mathrm{m}}$ & $2.6 \pm 0.5^{\mathrm{a}}$ & $2.5 \pm 0.5^{\mathrm{a}}$ & $2.5 \pm 0.4^{\mathrm{a}}$ & $\mathrm{P}>0.05$ & 0.16 & 0.27 \\
FSD (mm) & $21.3 \pm 2.6^{\mathrm{ab}}$ & $21.1 \pm 2.7^{\mathrm{b}}$ & $23.0 \pm 2.1^{\mathrm{a}}$ & $21.6 \pm 3.2^{\mathrm{ab}}$ & $\mathrm{P}<0.05$ & 0.12 & 1.83 \\
IPW (g) & $2.4 \pm 0.5$ & $2.3 \pm 0.4$ & $2.1 \pm 0.4$ & $2.1 \pm 0.6$ & $\mathrm{P}>0.05$ & 0.02 & 0.32 \\
FPW (g) & $243.5 \pm 60.0^{\mathrm{ab}}$ & $236.8 \pm 49.5^{\mathrm{b}}$ & $291.1 \pm 81.4^{\mathrm{a}}$ & $258.4 \pm 80.0^{\mathrm{ab}}$ & $\mathrm{P}<0.05$ & 0.28 & 47.89 \\
ILN & $3.9 \pm 0.4^{\mathrm{c}}$ & $4.5 \pm 0.6^{\mathrm{ab}}$ & $4.2 \pm 0.5^{\mathrm{bc}}$ & $4.8 \pm 0.8^{\mathrm{a}}$ & $\mathrm{P}<0.05$ & 0.14 & 0.40 \\
FLN & $37.1 \pm 4.3$ & $35.3 \pm 3.5$ & $35.6 \pm 3.9$ & $34.5 \pm 5.5$ & $\mathrm{P}>0.05$ & 0.12 & 2.79 \\
GR $(\%$ g/day) & $5.7 \pm 1.4^{\mathrm{b}}$ & $5.6 \pm 1.8^{\mathrm{b}}$ & $6.9 \pm 1.9^{\mathrm{a}}$ & $6.1 \pm 2.0^{\mathrm{ab}}$ & $\mathrm{P}<0.01$ & 0.28 & 1.14 \\
Shoot/root & $15.4 \pm 3.0^{\mathrm{b}}$ & $18.7 \pm 4.6^{\mathrm{a}}$ & $11.1 \pm 1.4^{\mathrm{c}}$ & $10.0 \pm 1.4^{\mathrm{c}}$ & $\mathrm{P}<0.01$ & 0.18 & 1.62 \\
Total Yield $\left(\mathrm{g} / \mathrm{m}^{2}\right)$ & 5072.2 & 4934.0 & 6067.4 & 5382.6 & & & \\
\hline
\end{tabular}

IPL= Initial Plant Length, FPL= Final Plant Length, IRL= Initial Root Length, FRL= Final Root Length, ISD= Initial Stem Diameter, FSD= Final Stem Diameter, ISD= Initial Plant Weight, FPW= Final Plant Weigth, ILN= Initial Leaf Number, FLN= Final Leaf Number, GR= Growth Rate, Values are given as mean $(n=3)$ with standard deviation.

There were a general increasing trend of dissolved anions such as calcium and sodium. A smooth increasing trend compared to other anions was the case for chloride concentrations with the change between 18.8 and 60.0 $\mathrm{mg} / \mathrm{L}$. There were no significant differences between the concentrations of any of these anions among the system units $(\mathrm{P}>0.05)$. Phosphate levels in all units increased up to $7 \mathrm{mg} / \mathrm{L}$ in all tanks (Figure 2), consistent with the observations of da Silva Cerozi and Fitzsimmons (2017). Phosphorus availability for plants rises with a decrease in $\mathrm{pH}$ and an increase in temperature (Cerozi et al., 2016).

Ion concentration in all tanks was found to be directly related to the $\mathrm{pH}$ level of aquaponics water. While ion concentrations in general increased with time, an opposite trend was the case for $\mathrm{pH}$ levels due to the bacterial conversion process of $\mathrm{NH}_{4}$ to $\mathrm{NO}_{3}$, which includes acidproducing reactions (Losordo et al. 2009). Decreasing pH in aquaponic is sought for increased solubilites and better availabilities of nutrients such as boron, $\mathrm{Fe}^{2+}, \mathrm{Mn}^{2+}, \mathrm{PO}_{4}{ }^{3-}$, $\mathrm{Ca}^{2+}$ and $\mathrm{Mg}^{2+}$ due for plant growth (Maucieri et al. 2019). $\mathrm{pH}$ exhibited lower values in the sump tank where hydroponic outlets are collected compared to other units $\left(\mathrm{F}_{a, b}=2.753, \mathrm{P}<0.05\right)$. This presumably was a result of more nitrification processes taking place in the plant production troughs. Concentrations of sulfate, one of the most essential nutrients for plant growth, showed a similar increasing trend in all tanks during the period of the study, as observed by Robinson et al. (2011). Despite an increase of sulfate concentrations, Villarroel et al. (2011) recommended supplemental sulfate for strawberry growth in the aquaponic system including tilapia.

Zou et al. (2016) found that $\mathrm{pH}$ has an opposite relationship between fish biomass increase $\left(\mathrm{kg} / \mathrm{m}^{3}\right)$ and plant biomass increase $\left(\mathrm{kg} / \mathrm{m}^{2}\right)$. When $\mathrm{pH}$ increases, plant biomass decreases while fish biomass increases were reported.

The FCR calculated as 0.66 is an excellent score in comparison with the FCR value of (Endut et al., 2010) 1.23-1.39, (Akinwole and Faturoti, 2007) 1.1-1.7 and, 0.85 (Eding and Kamstra 2001). There was no adverse effect of inorganic substrates on the survival rate of African catfish, the survival rate was $100 \%$ at the end of the study. The specific growth rate was $2.36 \%$.
Plant growth rate, final plant length, final root length, final stem diameter, final plant weight, shoot/root ratio, feed conversion ratio and yield differ significantly among substrate materials. At the end of the study, the maximum average final plant length (FPL) was $525.1 \pm 69.6 \mathrm{~mm}$ in the rock wool group, and the minimum average final plant length (FPL) was $326.5 \pm 34.6 \mathrm{~mm}$ in the gravel group with a statistically different $(\mathrm{P}<0.05)$. The maximum shoot/root ratio was in the rock wool group as $18.7 \pm 4.6 \mathrm{~mm}$ and minimum shoot/root ratio was observed in the gravel group with $10.0 \pm 1,4$. While the final heaviest average plant weight was observed in the zeolite group with 291.1 \pm 81.4 $\mathrm{g}$, the lightest final average weight was monitored in the rock wool group with $236.8 \pm 49.5$ g. Average plant productions are $5072 \mathrm{~g} / \mathrm{m}^{2}, 4924 \mathrm{~g} / \mathrm{m}^{2}, 6067 \mathrm{~g} / \mathrm{m}^{2}$, and 5382 $\mathrm{g} / \mathrm{m}^{2}$ fiber, rock wool, zeolite, and gravel respectively. The highest growth rate was observed in the zeolite group with $6,9 \pm 1,9 \% \mathrm{~g} /$ day (Table 2). Final leaf numbers of all groups have no statistically significant differences among them. The relatively higher final plant weight yield of the zeolite group can be explained by the adherence of total ammonium, nitrite and nitrate-nitrogen to the zeolite material (Maucieri et al. 2018). Zeolites are characterized by high ammonium and nitrate nitrogen adsorbers (Wang and Peng 2010; Mazeikiene et al., 2010). Rafiee and Saad (2006) compared natural zeolite substrates with a control group with no substrate, which is integrated with Nile tilapia (Oreochromis niloticus). They found the Zeolite group is more advantageous, approximately 5.5 times to control group in terms of yield. Sikawa and Yakupitiyage (2010) used sand and gravel substrate materials for growing lettuce in hybrid catfish (Clarias microcephalus $\mathrm{x}$ C. gariepinus) pond water. They found that filtered water increased lettuce yields by $87 \%$ (control), $63 \%$ (gravel) and $52 \%$ (sand). In this study, gravel substrate showed statistically important plant weight gain with zeolite substrate when compared with other substrates $(\mathrm{P}<0.05$, Table 2). In another study, rock wool and cotton wool substrates have been compared to establish plant yield. At the end of the study, the rock wool medium had a $17.6 \%$ higher common carp, Cyprinus carpio, average weight compared to cotton wool (Sirakov et. al., 2017). 

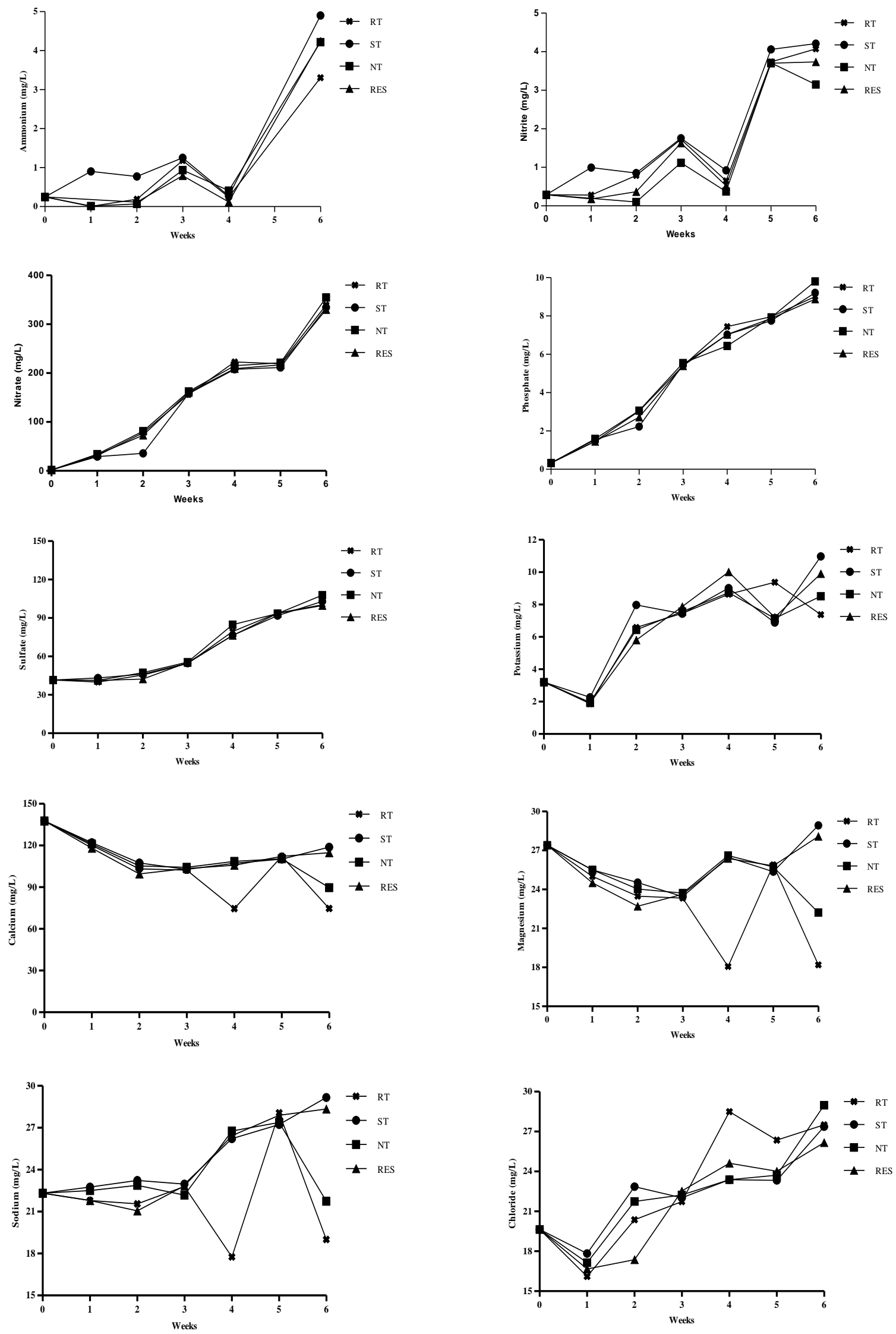

Figure 3. Ion concentrations of aquaponics' units

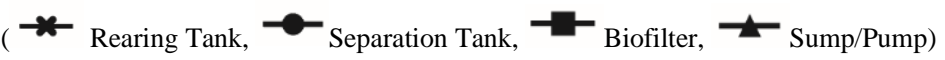




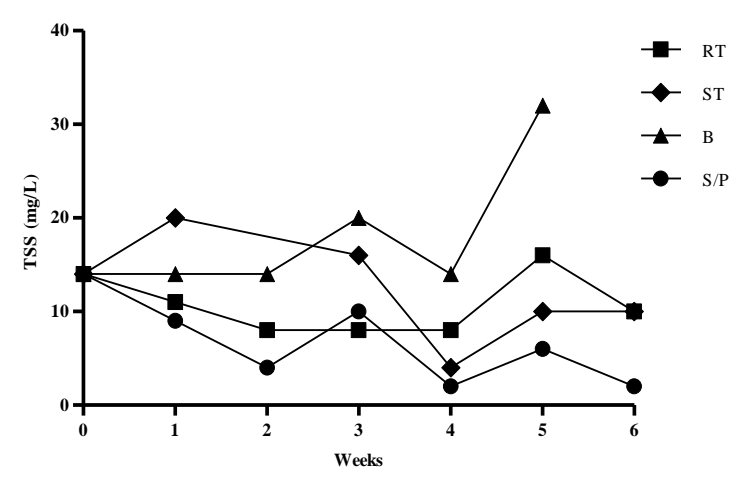

Figure 4. Total suspended solids of aquaponics' units

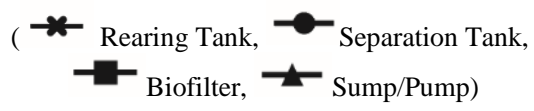

In lettuce hydroponics, different rock wool and perlite ratios have been compared with each other after 10 days. Also, $100 \%$ rock wool substrate had more than two times better results versus $100 \%$ perlite substrate considering wet weight (Tapia and Caro, 2009). Rock wool, fiber and zeolite have better final plant length results compared to gravel (Table 2). Clinoptilolite zeolite was used as a substrate for sweet pepper crops in a hydroponic system with its environmentally friendly properties. In recirculating hydroponic systems, plant uptake and zeolite substrate reduced nitrate-nitrogen levels in water (Harland et al, 1997). This adhesion property of zeolite can be an advantage for the final plant weight (Table 2). At the end of the study, maximum plant yield was calculated in the zeolite group as $6067 \mathrm{~g} / \mathrm{m}^{2}$, the minimum yield was measured in the fiber group as $5072 \mathrm{~g} / \mathrm{m}^{2}$.

In this study hydraulic retention rate was calculated as 20 times a day. In a study about the hydraulic retention rate of aquaponics, four different flow rates were examined: $50 \%, 100 \%, 200 \%$, and $400 \%$ with Ipomea aquatica, Lactuca sativa, and Canna glauca. The highest yield of the plants was found in $400 \%$ recirculation rate at the low fish density of $122 / \mathrm{m}^{3}$ (Trang et al. 2017).

Three different sized live feed species naturally occurred in plant raft unit which are Physella acuta, Daphnia pulex, and Cyclops vicinus. These species can eat naturally grown phytoplankton in troughs. Furthermore, these species may be used for the juvenile fish feeding also. This type of aquaponic system may use for alternatively live feed species' coproduction. $30 \%$ of international aquaponics practitioners use live feed for feeding fish in their aquaponics (Love et al., 2014), and 27\% of South African aquaponics practitioners use live feed in their aquaponics (Mchunu et al., 2018).

Parameters about plant growth indicate that the use of inorganic substrate even only in seedling baskets has a remarkable potential to affect lettuce development. Since we did not analyze each of the troughs separately in terms of ions, we cannot make a clear conclusion about the nutrient absorptions of lettuce kept in different substrates.

\section{Conclusions}

In this study, different substrates were examined to determine the best growing environment with fiber, rock wool, zeolite, and gravel. Fiber and rock wool substrate materials were not useful substrates as the plant's roots were difficult to separate from the substrate materials, and since they are filament-based, these materials cost much more by comparison with gravel and zeolite. These results indicate that the selection of relatively large gravel will be more profitable and more labor-friendly.

Thanks to African catfish' outstanding feed conversion rate, nitrogen in the water was well managed with the nitrification process. This study also suggests that intensive and extensive aquaculture facilities can modify their production units at a low cost to prevent discharge based unwanted eutrophication in Turkish freshwater.

Zeolite raft substrate results were better than the other substrates thanks to its particular nitrogen adhesive property. Rock wool substrate did not perform as well as zeolite, fiber and gravel substrates statistically. It was noticed that unsuitable sized gravels could block water flow in rafts. However, gravels were the cheapest substrate when compared to others. Fiber and rock wool have disadvantages in that they need to be wash fed to eliminate hazardous chemicals before use in aquaponics.

This research showed that zeolite, fiber and gravel substrates statistically significant differences among all substrates in yield, however the most economical substrate choice could be gravel for lettuce integrated with African catfish.

\section{Acknowledgements}

This research, project number 1190180, was supported by TUBITAK 1002 Fast Support Program. Services and supplies needed to sustain this project were provided by Mediterranean Fisheries Research, Production and Training Institute. This study "Integration of Microalgae on Aquaponics" was published during the project. I would like to give special thanks to director of Mediterranean Fisheries Research, Production and Training Institute (MEDFRI), Mr. Serkan Erkan and responsible engineer of MEDFRI Aquarium Unit Mr. Soner Sezen for their assistance. And, the authors would like to give another special thanks to James Cowin for his assistance in editing the English in this article.

\section{References}

Adler P. 2001. Overview of economic evaluation of phosphorus removal by plants. Aquaponics Journal. 5: 15-18.

Akinwole AO, Faturoti EO. 2007. Biological performance of African catfish (Clarias gariepinus) cultured in recirculating system in Ibadan. Aquacultural Engineering. 35: 18-23. https://doi.org/10.1016/j.aquaeng.2006.05.001

Antoniou P, Hamilton J, Koopman B, Jain R, Holloway B, Lyberatos G, Svoronos SA. 1990. Effect of temperature and $\mathrm{pH}$ on the effective maximum specific growth rate of nitrifiying bacteria. Water Res. 24: 97-101. https://doi.org/ 10.1016/0043-1354(90)90070-M

Abdullahi YA, Akunna JC, White NA, Hallett PD, Wheatley R. 2008. Investigating the effects of anaerobic and aerobic posttreatment on quality and stability of organic fraction of municipal solid amendment. Bioresource Technology. 99, 8631-8636. https://doi.org/10.1016/j.biortech.2008.04.027

APHA. 1998. Standart Methods for the Examination of Water and Wastewater. 20th edition. American Public Health Association, Washington, D.C. 
Baßmann B, Brenner M, Palm HW. 2017. Stress and welfare of African catfish (Clarias gariepinus Burchell, 1822) in a coupled aquaponic system. Water. 9(7): 504. https://doi.org/ 10.3390/w9070504

Baßmann B, Harbach H, Weißbach S, Palm HW. 2020. Effect of plant density in coupled aquaponics on the welfare status of African catfish, Clarias gariepinus. Journal of the World Aquaculture Society, 51(1): 183-199. https://doi.org/ 10.1111/jwas. 12574

Blackburne R, Vadivelu VM, Yuan Z, Keller J. 2007. Kinetic characterisation of an enriched Nitrospira culture with comparison to Nitrobacter. Water Res. 41: 3033-3042. https://doi.org/10.1016/j.watres.2007.01.043

Cebron A, Garnier J. 2005. Nitrobacter and Nitrospira genera as representatives of nitrite-oxidizing bacteria: Detection, quantification and growth along the lower Seine River (France). Water Res. 39 (20): 4979-4992. https://doi.org/ 10.1016/j.watres.2005.10.006

Cerozi BD, Fitzsimmons K. 2016. The effect of $\mathrm{pH}$ on phosphorus availability and speciation in an aquaponics nutrient solution. Bioresource Technology. 219: 778-781 https://doi.org/10.1016/j.biortech.2016.08.079

Chen SL, Coffin DE, Malone RF. 1997. Sludge production and management for recirculating aquacultural systems. Journal of World Aquaculture Society, 28(4): 303-315. https://doi.org/ 10.1111/j.1749-7345.1997.tb00278.x

Da Silva Cerozi B, Fitzsimmons K. 2017. Effect of dietary phytase on phosphorus use efficiency and dynamics in aquaponics. Aquaculture International, 1-12. https://doi.org/ 10.1007/s10499-016-0109-7.

Danaher JJ, Shultz RC, Rakocy JE, Bailey DS. 2013. Alternative solids removal for warm water recirculating raft aquaponic systems. Journal of the World Aquaculture Society, 44(3): 374-383. https://doi.org/10.1111/jwas. 12040

Davidson J, Helwig N, Summerfelt ST. 2008. Fluidized sand biofilters used to remove ammonia, biochemical oxygen demand, total coliform bacteria, and suspended solids from an intensive aquaculture effluent. Aquacultural Engineering, 39(1): 6-15. https://doi.org/10.1016/j.aquaeng.2008.04.002

Ebeling JM, Timmons MB. 2012. Recirculating aquaculture systems J.H. Tidwell (Ed.), Aquaculture Production Systems, Wiley-Blackwell (2012), pp. 245-277.

Eding E, Kamstra A. 2001. Design and performance of recirculation systems for European eel and African catfish. In: Porceeding of AES Workshop, January 23, Orlando, Florida, USA. pp. 18-28.

Endut A, Jusoh A, Ali N, Wan Nik WB, Hassan A. 2010. A study on the optimal hydraulic loading rate and plant ratios in recirculation aquaponics system. Bioresource Technology. 101: 1511-1517. https://doi.org/10.1016/j.biortech.2009.09.040

FAO 2016. http://www.fao.org/nr/water/aquastat/data/query/ results.html

Geisenhoff LO, Rodrigo AJ, Santos RC, Oliviera FC, Gomes EP. 2016. Effect of different substrates in aquaponics lettuce production associated with intensive tilapia farming with water recirculation systems. Journal of the Brazilian Association of Agricultural Engineering. 36(2): 291-299. https://doi.org/ 10.1590/1809-4430-Eng.Agric.v36n2p291-299/2016

Gell K, Van Groenigen JW, Cayuela ML. 2011. Residues of bioenergy production chains as soil amendments: immediate and temporal phytotoxicity. Journal of Hazardous Materials. 186, 2017-2025. https://doi.org/10.1016/j.hazmat.2010.12.105

Hagopian DS, Riley JG. 1998. A closer look at the bacteriology of nitrification. Aquacultural Engineering. 18: 223-244.

Harland J, Lane S, Price D. 1997. Further experiences with recycled zeolite as a substrate for the sweet pepper crop. In International Symposium on Growing Media and Hydroponics. 481: 187-196.
Hogendoorn H, Jansen JAJ, Koops WJ, Machiels MAM, Van Ewijk PH, Van Hees JP. 1983. Growth and production of the African catfish, Clarias lazera (C. \& V.): II. Effects of body weight, temperature and feeding level in intensive tank culture. Aquaculture, 34(3-4): 265-285.

Jhingran VG. 1991. Fish and Fisheries of India. $3^{\text {rd }}$ ed. Hindustan Publishing Corporation. Delhi, India. 727.

Jordan RA, Riberio EF, Oliveira FC, Geisenhoff LO, Martins EAS. 2018. Yield of lettuce grown in hydroponic and aquaponics systems using different substrates. Revista Brasileira de Engenharia Agricola e Ambiental. 8: 525-529. https://doi.org/10.1590/1807-1929/agriambi.v22n8p525-529

Khandaker M, Kotzen B. 2018. The potential for combining living wall and vertical farming systems with aquaponics with special emphasis on substrates. Aquaculture Research. 49, 1454-1468. doi:10.1111/are.13601

Lennard WA, Leonard BV. 2006. A comparison of three different hydroponic sub-systems (gravel bed, floating and nutrient film technique) in an aquaponic test system. Aquaculture International. 14:539-550. doi:10.1007/s10499-006-9053-2

Losordo T, DeLong D, Guerdat T. 2009. Advances in technology and practice for land-based aquaculture systems: tank-based recirculating systems for finfish production. In New Technologies in Aquaculture (pp. 945-983). Woodhead Publishing. https://doi.org/10.1533/9781845696474.6.945

Love DC, Fry JP, Genello L, Hill ES, Frederick JA, Li X, Semmens K. 2014. An international survey of aquaponics practitioners. PloS one, 9(7): e102662. https://doi.org/10.1371/ journal. pone. 0102662

Marschner H. 2003. Mineral nutrition of higher plants. Academic Press, San Diego, California. doi:10.1146/annurev.pp.31

Maucieri C, Nicoletto C, Junge R, Schmautz Z, Sambo P, Borin M. 2018. Hydroponic systems and water management in aquaponics: A review. Italian Journal of Agronomy. 13, 1012-1023.

Maucieri C, Nicoletto C, Van Os, E, Anseeuw D, Van Havermaet R, Junge R. 2019. Hydroponic technologies. In Aquaponics Food Production Systems (pp. 77-110). Springer, Cham.

Mažeikiene A, Valentukevičiene M, Rimeika M, Matuzevičius A B, Dauknys R. 2008. Removal of nitrates and ammonium ions from water using natural sorbent zeolite (clinoptilolite). Journal of Environmental Engineering and Landscape Management, 16(1): 38-44. https://doi.org/10.3846/16486897.2008.16.38-44

Mchunu N, Lagerwall G, Senzanje A. 2018. Aquaponics in South Africa: Results of a national survey. Aquaculture Reports, 12, 12-19. https://doi.org/10.1016/j.aqrep.2018.08.001

McMurtry MR, Nelson PV, Sanders DC. 1990. Sand culture of vegetables using recirculated aquacultural effluents. Applied Agricultural Research, 5, p. 280-284.

McMurtry MR, Sanders DC, Cure JD, Hodson RG. 1997. Effects of biofilter/culture tank volume ratios on productivity of a recirculating fish/vegetable co-culture system. Journal of Applied Aquaculture. 7:33-51. doi:10.1300/j028v07n04_03

Milicic V, Thorarinsdottir R, Santos MD, Hancic MT. 2017. Commercial aquaponics approaching the European Market: To consumers' perceptions of aquaponics products in Europe. Water, 9(2): 80-102. https://doi.org/10.3390/w9020080

Molden D. 2017. Water for Food, Water for Life: A Comprehensive Assessment of Water Management in Agriculture. London; Colombo: Earthscan; International Water Management Institute, 39s. https://doi.org/10.1007/ s10795-008-9044-8

Nelson RI. 2007. Ten aquaponic systems around the world. Aquaponics Journal. 46:8-12.

Nicola S, Hoeberechts J, Fontana E. 2005. Comparison between traditional and soilless culture systems to produce rocket (Eruca sativa) with low nitrate content. Acta Horticulturae. 697: 549555. https://doi.org/10.17660/ActaHortic.2005.697.72 
Nuwansi KKT, Verma AK, Prakash C, Tiwari VK, Chandrakant MH, Shete AP, Prabhath GPWA. 2016. Effect of water flow rate on polyculture of koi carp (Cyprinus carpio var. koi) and goldfish (Carrasius auratus) with water spinach (Ipomoea aquatica) in recirculating aquaponic system. Aquaculture. https://doi.org/10.1007/s10499-015-9932-5

Palm HW, Bissa K, Knaus U. 2014. Significant factors affecting the economic sustainability of closed aquaponic systems. Part II: fish and plant growth. Aquaculture, Aquarium, Conservation \& Legislation. 7(3): 162-175.

Rakocy JE. 1984. A recirculating system for tilapia culture and vegetable hydroponics. Smitherman R. O., Trave D., (ed). Auburn Symposium on Fisheries and Aquaculture. Auburn, AL. p. 103-114.

Rakocy JE, Bailey DS, Schultz KA, Cole WM. 1997. Evaluation of a commercial-scale aquaponic unit for the production of tilapia and lettuce. 4th International Symposium on Tilapia in Aquaculture. 1: 357-372.

Rakocy JE, Bailey DS, Schultz RC, Thoman ES. 2004. Update on tilapia and vegetable production in the UVI aquaponic system. 31 October 2019. https://cals.arizona.edu/ azaqua/ista/ista6/ista6web/pdf/676.pdf

Rakocy JE, 2012. Aquaponics: integrating fish and plant culture. Aquaculture production systems. 1, 343-386.

Robinson MV, Alvarino JR, Duran M. 2011. Aquaponics: integrating fish feeding rates and ion waste production for strawberry hydroponics. Spanish Journal of Agricultural Research. 9(2): 537-545.

Roosta HR, Afsharipoor S. 2012. Effects of different cultivation media on vegetative growth, ecophysiological traits and nutrients concentration in strawberry under hydroponic and aquaponics cultivation systems. Advances in Environmental Biology. 6(2): 543-555.

Sanchez M, Gomez X, Barriconal G, Cuetos MJ, Morani A. 2008. Assessment of the stability of livestock farm wastes treated by anaerobic digestion. Int. Biodeterior. Biodegrad. 62, 421426. https://doi.org/10.1016/j.ibiod.2008.04.002

Schram E, Roques JA, Abbink W, Yokohama Y, Spanings T, de Vries P, Flik G. 2014. The impact of elevated water nitrate concentration on physiology, growth and feed intake of African catfish Clarias gariepinus (Burchell 1822). Aquaculture research. 45(9): 1499-1511. https://doi.org/ 10.1111/are. 12098

Sengbusch VR, Meske CH, Szablewski W, Lühr B. 1967. Gewichtszunahme von Karpfen in Kleinstbehaltern, zugleich ein Beitrag zur Aufklarung des Raumfaktors. Z. Fisch. 15 (1/2): 45-60.

Sneed K, Allen K, Ellis JE. 1975. Fish Farming and Hydroponics. Aquaculture and Fish Farmer. 11 p. 11-18. https://doi.org/ 10.1371/journal.pone.0102662.

Sikawa DC, Yakupitiyage A. 2010. The hydroponic production of lettuce (Lactuca sativa $\mathrm{L}$ ) by using hybrid catfish (Clarias microcephalus x C. gariepinus) pond water: Potentials and constraint. Agr. Water Manage. 97: 1317-1325. https://doi.org/ 10.1016/j.agwat.2010.03.013

Sirakov I, Velichkova K, Stoyanova S, Slavcheva-Sirakova D, Staykov Y. 2017. Comparison between two production technologies and two types of substrates in an experimental aquaponics recirculation system. Sci. Pap. Ser. E-Land Reclam. Earth Obs. Surv. Environ. Eng. 6, 98-103.
Somerville C, Cohen M, Pantanella E, Stankus A, Lovatelli A. 2014. Small-scale aquaponic food production: integrated fish and plant farming. FAO Fisheries and Aquaculture Technical Paper. (589), I.

Strauch SM, Wenzel LC, Bischoff A, Dellwig O, Klein J, Schüch A, Wasenitz B, Palm HW. 2018. Commercial African catfish (Clarias gariepinus) recirculating aquaculture systems: Assessment of element and energy pathways with special focus on the phosphorus cycle. Sustainability. 10(6): 1805. https://doi.org/10.3390/su10061805

Tapia ML, Caro JM. 2009. Production of lettuce seedlings (Lactuca sativa) in granular rock wool and expanded perlite for use in hydroponics. Ciencia e investigacion agrarian: revista latinoamericana de ciencias de al agricultura. 36(3): 401-410.

Toko I, Fiogbe ED, Koukpode B, Kestemont P. 2007. Rearing of African catfish (Clarias gariepinus) and vundu catfish (Heterobranchus longifilis) in traditional fish ponds (whedos): Effect of stocking density on growth, production and body composition. Aquaculture, 262(1): 65-72. https://doi.org/ 10.1016/j.aquaculture.2006.08.054

Trang NTD, Konnerup D, Brix H. 2017. Effects of recirculation rates on water quality and Oreochromis niloticus growth in aquaponics systems. Aquacultural Engineering. 78: 95-104. https://doi.org/10.1016/j.aquaeng.2017.05.002

Tyson RV. 2004. Reconciling water quality parameters impacting nitrification in aquaponics: The $\mathrm{pH}$ levels. Proceedings of the Florida State Horticultural Society. 117: 79-83.

Tyson RV, Simonne EH, Treadwell DD, White JM, Simonne A. 2008. Reconcilling $\mathrm{pH}$ for ammonia biofiltration and cucumber yield in a recirculating aquaponic system with perlite biofilters. HortScience 43:719-724. https://doi.org/ 10.21273/HORTSCI.43.3.719

Tyson RV, Treadwell DD, Simonne EH. 2011. Opportunities and challenges to sustainability in aquaponic systems. Horttechnology 21(1): 6-13. doi:10.21273/HORTTECH.21.1.6

Velichkova K, Sirakov I, Stoyanova S, Staykov Y. 2019. Cultivation of lettuce (Lactuca sativa L.) and rainbow trout (Onchorynchus mykiss W.) in the aquaponics recirculation system. Journal of Central European Agriculture. 20(3): 967973. https://doi.org/10.5513/JCEA01/20.3.2223

Wang S, Peng Y. 2010. Natural zeolites as effective adsorbents in water and wastewater treatment. Chem. Eng. J. 156, 11-24. https://doi.org/10.1016/j.cej.2009.10.029

Watten BJ, Busch RL. 1984. Tropical production of tilapia (Sarotherodon aurea) and tomatoes (Lycopersicon esculentum) in a small-scale recirculation water system. Aquaculture. 41:271-283. https://doi.org/10.1016/00448486(84)90290-4

Wurts WA. 2003. Daily pH cycle and ammonia toxicity. World Aquaculture. 34(2): 20-21.

Zou Y, Hu Z, Zhang J, Xie H, Guimbaud C, Fang Y. 2016. Effects of $\mathrm{pH}$ on nitrogen-based aquaponics. Bioresource Technology. 210, 81-87. https://doi.org/10.1016/j.biortech. 2015.12.079. 